\title{
Effect of Hydrothermal, Phytase, or Organic Acid Pretreatments of Canola Meal on Phytate Level of the Meal
}

\author{
Enkhjargal Darambazar ${ }^{1}$, Daalkhaijav Damiran ${ }^{1} \&$ Denise Beaulieu ${ }^{1}$ \\ ${ }^{1}$ Department of Animal and Poultry Science, University of Saskatchewan, 51 Campus Drive, Saskatoon, SK S7N \\ 5A8, SK, Canada \\ Correspondence: Daalkhaijav Damiran, Department of Animal and Poultry Science, University of Saskatchewan, \\ 51 Campus Drive, Saskatoon, SK S7N 5A8, Canada. Tel: 306-966-4173. E-mail: daal.damiran@ usask.ca
}

Received: August 22, 2019 Accepted: September 6, 2019 Online Published: September 17, 2019

doi:10.5539/sar.v8n4p35

URL: https://doi.org/10.5539/sar.v8n4p35

\begin{abstract}
The objective of this study was to investigate the effect of pretreatment of canola meal with hydrothermal processing, phytase, and organic acid on phytate degradation. Six experiments were conducted processing canola meal in a hydrothermal reactor with different moisture conditions (15-350\%), acid additions (hydrochloric acid, citric acid, malic acid, and lactic acid), $\mathrm{pH}(\mathrm{pH} \mathrm{4,5}$, and 6), incubation times (30, 45, and $60 \mathrm{~min})$, and phytase enzymes ('Quantum Blue' and 'Finase'). The study revealed that although hydrothermal pretreatment of canola meal with phytase and higher moisture (200-350\%) would allow 24.8-36\% phytate breakdown, and a higher moisture addition (200\%) combined with organic acid increased even further to $46.6 \%$, lower moisture (50 and $100 \%$ ) and organic acid was still effective in reducing phytate (by 7.9-19.4\%). Optimal pH and incubation time in hydrothermal reactor for phytase efficacy were determined to be $\mathrm{pH} 4$ and 5 and 30 to $60 \mathrm{~min}$. Still, the results of the current study suggest that pretreatments should be further evaluated to optimize the efficacy of enzyme and organic acids as prebiotics to reduce anti-nutrients in canola meal, thus improving its utilization for livestock and reducing excretion to environment.
\end{abstract}

Keywords: canola meal, phytate, enzyme additive, hydrothermal reactor

\section{Introduction}

Canola meal is a commonly used feed ingredient for monogastrics, however, its nutritional value is limited by the high level of nonstarch polysaccharides and anti-nutrients, such as phytate [or phytic acid (PA)]. Canada's 13 crushing and refining plants have the capacity to crush about 9.0 million tonnes of canola seed, and produce about 3.6 million tonnes of canola oil and 5.4 million tons of canola meal (CM; 42.6\% CP, 71.5\% TDN in DM basis; Damiran, Lardner, Larson, \& McKinnon, 2016) annually (Canola Council of Canada, 2014). Canola meal is considered a relatively high phytate feedstuff containing 3.1-6\% PA (Cheryan, 1980; McCurdy \& March, 1992; Al-Asheh \& Duvnjak, 1994) in solvent extracted (commercial) canola meal (SECM). This is almost twice the phytate content of soybean meal (SBM). However, it also, contains $0.38 \%$ nonphytate (available) P, higher than SBM, cottonseed meal, wheat, wheat bran, corn, or barley, at $0.28,0.23,0.09,0.26,0.07$, and $0.13 \%$, respectively (Khajali \& Slominski, 2012). Phytic acid decreases mineral, especially phosphorus (P) digestibility in monogastrics and can form complexes with proteins, thus reducing their availability for absorption (Al-Asheh \& Duvnjak, 1994; Bedford, 2000; Maenz, 2001; Viveros, Brenes, Arija, \& Centeno, 2002).

Phosphorus has become one of the major contributors to environmental pollution. It is estimated that about $80 \%$ of inorganic $\mathrm{P}$ is wasted and the buildup of bioavailable $\mathrm{P}$ contributes to eutrophication of ground water (Zvomuya et al., 2006; Cordell, 2010). For the sake of sustainability, P must be recovered in an uncontaminated and plant-available form (Schröder, Cordell, Smit, \& Rosemarin, 2009). Phosphorus is mainly excreted in the feces; grow-finish pigs excrete 63\% of the P consumed (van der Peet-Schwering, 1998). Moreover, supplementing inorganic $\mathrm{P}$ for livestock increases diet cost.

Utilization of CM can be improved using exogenous enzymes (Slominski, Campbell, \& Guenter, 1992; Simbaya, Slominski, Guenter, Morgan, \& Campbell, 1996). Supplementation of microbial phytase to swine diets improves the absorption and utilization of P in feed ingredients of plant origin (Simons et al., 1990; Cromwell, Stahly, Coffey, Monegue, \& Randolph, 1993; Lei, Ku, Miller, \& Yokoyama, 1993a; Lei, Ku, Miller, Yokoyama, \& Ullrey, 1993b; Slominski, Cyran, Guenter, \& Campbell, 1999) along with lowering P excretion by 20 to $50 \%$ 
(Simons et al., 1990; Beers \& Jongbloed, 1992; Lei \& Stahl, 2000; Emiola, Akinremi, Slominski, \& Nyachoti, 2009; Casas \& Stein, 2015). Doses of phytase from 500 to $4000 \mathrm{U} / \mathrm{kg}$ diet have been reported to have efficacy (Beers \& Jongbloed, 1992; Slominski et al., 1999; Adeola, Sands, Simmins, \& Schulze, 2004; Beaulieu, Bedford, \& Patience, 2007; Khan, Chaudhry, Butt, Jameel, \& Ahmad, 2013; Dersjant-Li \& Dusel, 2019), and as in an early study of superdosing by Nelson, Shieh, Wodzinski, and Ware (1971), phytate was hydrolysed to $94.4 \%$ with 7,600 FTU/kg of phytase produced by Aspergillus ficuum and to 100\% with 4800 and $48000 \mathrm{FTU} / \mathrm{kg}$ of two fungal phytases in a more recent study (Liu, 2014). Pretreatments of feed or feed ingredient, as Newkirk and Classen (1998) suggested, may increase phytate phosphorus hydrolysis before and during feeding. Processing of $\mathrm{CM}$ in hydrothermal reactors (HTR) used during conditioning of oilseeds and desolventising the meal with addition of feed enzymes, can be an effective treatment for breaking weak bonds between polysaccharides in the cell wall, opening the cell wall structure and reducing particle size, thereby increasing the surface area accessible for enzymes, both endogenous and feed added (exogenous) (de Vries, Pustjens, Kabel, Kwakkel, \& Gerrits, 2014).

Moreover, exogenous enzymes and organic acids act as prebiotics, selectively stimulating the growth of beneficial bacteria. Additionally, organic acids may also improve gastrointestinal function by reducing, digesta $\mathrm{pH}$, and improving digestive enzyme and microbial phytase activity (Jongbloed, Mroz, van Derweij-Jongbloed, \& Kemme, 2000; Dibner \& Buttin, 2002). Results from Li et al. (2008) suggested that the improved growth performance of weaned pigs fed a diet with a dry organic acid blend might be mainly by reducing pathogenic bacteria and increasing the beneficial bacterial population in the gut and feces. Also, Tsukahara, Koyama, Okada, \& Ushida, (2002) noted that gluconic acid reaches the pig large intestine to stimulate lactic acid bacteria, hence may be useful as a prebiotic to stimulate butyrate production in the large intestine. Furthermore, a potential of significantly improving iron bioavailability with fermentation or addition of small amounts of lactic acid to maize products was proposed by Proulx and Reddy (2007).

Others have implied of a feasibility to replace inorganic $\mathrm{P}$ supplementation for pigs (calcium phosphate) adding wheat middlings (as a cereal phytase source), microbial phytase, and citric acid (1.5\%) to corn-soybean meal (Han, Roneker, Pond, \& Lei, 1998) or achieved some results with phytase alone as in Emiola et al. (2009). More on potential additive effects of organic acids and enzymes, as studies revealed, supplementation with EDTA, citrate, and phthalate increased the efficacy of microbial phytase in hydrolyzing phytic acid (Maenz, Engele-Schaan, Newkirk, \& Classen, 1999), citric acid and phytase affected phytate-P utilization in chicks (Boling, Webel, Mavromichalis, Parsons, \& Baker, 2000), and increased Ca, P, Fe, and Zn retention (Lei \& Stahl, 2000; Viveros et al., 2002; Adeola et al., 2004), however, others found that the growth response to phytase was depressed by citric acid in chicks (Brenes et al., 2003).

Several factors may influence the efficacy of phytase, including the type and amount of phytase, method of inclusion, method of pretreatment, other ingredients, concentrations of nutrients (especially protein and minerals), and the animal species (Sajjadi \& Carter, 2004). Effects of HTR processing conditions alone or in combination with enzyme and organic acids on chemical characteristics and nutritional quality of canola meal are less known and require better characterization to maximize effective use. The objective of this study was to determine optimal parameters of canola meal pretreatments, in particular, processing the meal in hydrothermal reactor with added phytase and organic acid and investigate the effects on phytate level of the meal.

\section{Materials and Methods}

\subsection{Sample Preparation}

Solvent extracted canola meal (SECM; var. Brassica napus) was obtained from the Canadian Feed Research Centre (North Battleford, SK, Canada), ground in a coffee grinder for even consistency and stored in plastic pails under dry and cool conditions $\left(2-4^{\circ} \mathrm{C}\right)$. Samples from each treatment and replicate were dried in a forced air oven at $80^{\circ} \mathrm{C}$ for $48 \mathrm{~h}$ and then ground using Retsch ZM200 grinder (Retsch, Haan, Germany) via 0.5 or $1 \mathrm{~mm}$ screens prior to further analysis.

\subsection{Chemicals and Enzymes}

Analytical grade reagents were purchased from Sigma-Aldrich Canada (Oakville, ON) and Fisher Scientific Canada (Ottawa, ON); hydrochloric acid ( $\mathrm{HCl})$ of $1 \mathrm{M}$ concentration, citric acid (CA) and malic acid (MA) in powder, of $100 \%$ purity and lactic acid (LA) in liquid form, of $80 \%$ purity were used for the experiments. Enzymes used for the experiments were phytases; Quantum Blue 5G (declared potency of $5000 \mathrm{FTU} / \mathrm{g}$; Quantum ${ }^{\circledR}$ Blue; EC 3.1.3.26; AB Vista, Wiltshire, UK) and Finase EC 5P (declared potency of 5000 FTU/g; Finase ${ }^{\circledR}$ P, EC 3.1.3.8; AB Vista, Wiltshire, UK). Quantum Blue is an E. coli-derived 6-phytase and Finase is an A. niger-derived 3-phytase, that initiate dephosphorylation from position 6 and 3, respectively, on the 
myo-inositol ring. These phytases developed specifically for use in swine and poultry feeds belong to the class of histidine acid phytases (Greiner \& Bedford, 2010). Both enzymes are thermostable (maximum recommended temperature for Quantum Blue is $\left.90.5^{\circ} \mathrm{C}\right)$, water soluble, $\mathrm{pH}$-value is 4.5-5 $(100 \mathrm{~g} / \mathrm{L})$, and were supplemented according to their activity determined at standard conditions $\left(\mathrm{pH} 5.5,37^{\circ} \mathrm{C}, 5 \mathrm{mmol} / \mathrm{L}\right.$ sodium phytate) (ABVista Feed Ingredients, ABVista, Inc.).

\subsection{Experimental Design}

Six HTR experiments were conducted designed to investigate the HTR processing parameters and feed additives: 1) moisture additions, 2) phytase addition, 3) pH, 4) incubation times, 5) acids, and 6) phytase types. Unless specified otherwise, parameters throughout the experiments were: $100 \%$ moisture addition [or $1: 1(\mathrm{wt} / \mathrm{wt})$ as water/sample ratio], $\mathrm{pH} 4$ (adjusted using $\mathrm{HCl}$ ), incubation time $30 \mathrm{~min}$, incubation temperature $40^{\circ} \mathrm{C}$, and phytase type 'Quantum Blue' at a rate of $0.02 \%$ to contain $1000 \mathrm{FTU} / \mathrm{g}$ activity, where the latter two factors (incubation temperature and phytase inclusion rate) were kept constant throughout.

HTR experiment 1 (Exp. 1) aiming to evaluate the effect of moisture on PA level with different amounts of moisture addition (15 to $350 \%$ ) and phytase to $\mathrm{CM}$ was conducted in completely randomized design (CRD) with moisture as the treatment.

In HTR experiment 2 (Exp. 2), phytase effect on PA level was evaluated in CRD where phytase was the treatment.

In HTR experiments 3, 4, and 5, $\mathrm{pH}$ (pH 4.0, 5.0, and 6.0) (Exp. 3; $3 \times 3$ ), incubation times (30, 45, and $60 \mathrm{~min})$ (Exp. 4; $3 \times 3$ ), and phytase types ('Quantum Blue' and 'Finase') (Exp. 5: $2 \times 3$ ) with acids (hydrochloric acid $(\mathrm{HCl})$, citric acid (CA), and malic acid (MA) were tested to determine the optimal parameters for phytase efficacy in split plot design.

In HTR experiment 6 (Exp. 6), in an effort to further reduce the moisture in CM to better adjust for feed mill production condition, $\mathrm{CM}$ was tested with a lower amount of moisture addition (50\% vs. $100 \%)$, phytase, and organic acid in $2 \times 3$ factorial arrangement.

Treatments were replicated ( $\mathrm{n}=4$ to 10 ) and results were compared with untreated CM (Control 0 ). It should be noted that in Exp. 2, 5, and 6, a no-enzyme treatment (No Enzyme) was included to compare the effects of moisture or $\mathrm{HCl}$ alone, without or with phytase.

\subsection{Hydrothermal Reactor Run Procedure}

A bench-scale HTR with some modifications to adjust for the laboratory conditions were used (Figure 1) for this study. This equipment consisted of a water bath and heater/circulator (ANOVA, Anova Culinary LLC, Houston, TX, USA), a 12-cell double metal rack for the $12 \mathrm{cups} /$ containers (500 $\mathrm{mL}$ capacity), 12 powered mixer-heads with removable spiral stirrers capable of generating speeds up to $450 \mathrm{rpm}$, and a power generator with corresponding cables.

After the water obtained the desired temperature, one hundred grams of CM was weighed into each cup followed by the addition of the required amount of water. The $\mathrm{pH}$ was measured while mixing the meal intensively with the power stirrer, using a $\mathrm{pH}$-meter $(\mathrm{H} 160, \mathrm{HACH}$, Loveland, $\mathrm{CO}, \mathrm{USA})$ and adjusted to the desired level using $1 \mathrm{M} \mathrm{HCl}$ solution or organic acid.

The canola meal was conditioned in the pre-heated water bath for 15 min while stirring at $\sim 450 \mathrm{rpm}$ speed continuously until the meal temperature became $40^{\circ} \mathrm{C}$, the enzyme solution containing phytase $1000 \mathrm{FTU} / \mathrm{kg}$ activity (or supplements) were then added. At the end of incubation, the reaction was stopped by increasing the $\mathrm{pH}$ to 9.0 with the addition of $20 \%$ sodium hydroxide solution. The sample was dried in a forced-air oven and ground using Retsch ZM100 grinder (Retsch, Haan, Germany) via $1 \mathrm{~mm}$ screen for chemical analysis and via 0.5 $\mathrm{mm}$ screen for phytate and SCP determinations. 


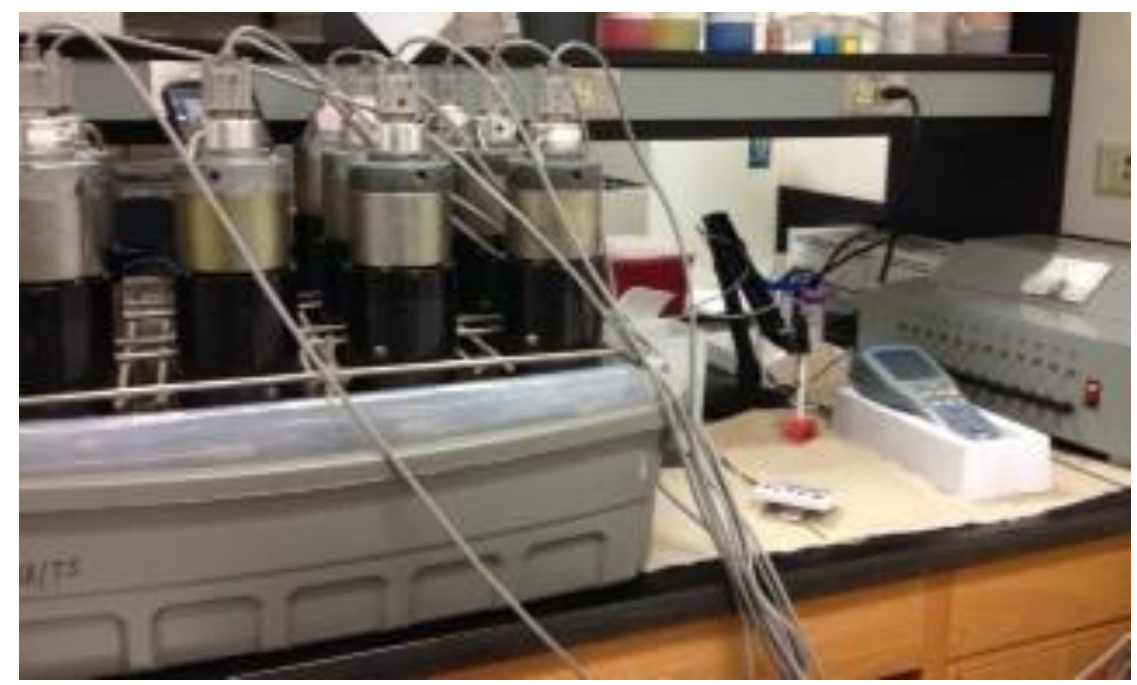

Figure 1. A bench-scale hydrothermal reactor used in the study

\subsection{Chemical Analysis}

\subsubsection{Moisture, $\mathrm{pH}$, and Other Analysis}

Moisture content (\%) of hydrothermally treated sample was determined using a two-step method (Method 930.15; AOAC, 2000). Sample pH was measured using a pH-meter (H160, HACH, Loveland, CO, USA). Crude protein $(\mathrm{CP})$ was determined by the combustion method using a LECO FP-528 total nitrogen analyzer (St. Joseph MI, USA) and calculated as N×6.25 (Method 968.06, AOAC 2000). Determination of total soluble crude protein (SCP) involved an incubation of the sample in bicarbonate-phosphate buffer and filtration through Whatman \#54 filter paper followed by Kjeldahl-N analysis as described by Roe, Sniffen, and Chase (1990).

\subsubsection{Phytate Determination}

Phytate determination was based on the colorimetric method of Gao et al. (2007) with some modifications described by Darambazar (2018). Briefly: samples weighing $0.5 \pm 0.01 \mathrm{~g}$ were extracted in $10 \mathrm{~mL}, 2.4 \%(0.64 \mathrm{~N})$ hydrochloric acid $(\mathrm{HCl})$ for $16 \mathrm{~h}$ with shaking at $300 \mathrm{rpm}$ on a platform shaker (VWR Advanced Digital Shaker Model 3750), followed by centrifugation at $3000 \mathrm{rpm}$ and $10^{\circ} \mathrm{C}$ for $20 \mathrm{~min}$ in an Avanti J-E Centrifuge (Beckman-Coulter Mississauga, ON, Canada). The supernatant was filtered through Whatman \#1 filter paper into a tube containing $1.0 \pm 0.01 \mathrm{~g}$ of Sodium Chloride $(\mathrm{NaCl})$ and the mixture was stirred until the salt dissolved, followed by continued mixing at $300 \mathrm{rpm}$ for $20 \mathrm{~min}$. The precipitate was allowed to settle at $2-4^{\circ} \mathrm{C}$ for $60 \mathrm{~min}$ or at $-20^{\circ} \mathrm{C}$ for $20 \mathrm{~min}$ and then centrifuged at $3000 \mathrm{rpm}$ and $10^{\circ} \mathrm{C}$ for $20 \mathrm{~min}$. One milliliter of supernatant was taken into a $25 \mathrm{~mL}$ - volumetric flask and diluted with $24 \mathrm{~mL}$ deionized water. Sodium phytate standard stock solution was prepared using phytic acid sodium salt hydrate (from rice, $\mathrm{C}_{6} \mathrm{H}_{18} \mathrm{O}_{24} \mathrm{P}_{6} \cdot \mathrm{xNa} \cdot \mathrm{yH}_{2} \mathrm{O} ; 79 \%$ purity and 20.6\% P as is; Sigma Aldrich, St. Louis P8810; CAS 14306) and standards of 0, 5, 10, 30, 60, and $80 \mathrm{mg} / \mathrm{mL}$ concentrations were prepared for a calibration curve. In a test tube, $3 \mathrm{~mL}$ of the diluted sample and standards was combined with $1 \mathrm{~mL}$ of Wade Reagent (Ferric Chloride Hexahydrate $\left(\mathrm{FeCL}_{3} \cdot 6 \mathrm{H}_{2} \mathrm{O}\right)$, Fisher Scientific CAS F2877), mixed on a vortex and centrifuged at $3000 \mathrm{rpm}$ and $10^{\circ} \mathrm{C}$ for $10 \mathrm{~min}$. Absorbance of color reaction was read at $500 \mathrm{~nm}$ on a spectrophotometer (Ultrospec III UV/Visible Spectrophotometer, Pharmacia Model 80-2097-62 LKB Biochrom, England). The analysis was done in duplicates.

\subsection{Statistical Analysis}

Experiment 1 was conducted using a completely randomized design (CRD) with moisture as the treatment. In Exp. 2, the effect of phytase enzyme on phytate level was tested in a CRD with phytase as the treatment. The model used for Exp. 1 and 2 was: $Y_{i j}=\mu+T_{i}+e_{i j}$; where $Y_{i j}$ was an observation of the dependent variable $i j ; \mu$ was the population mean for the variable; $T_{i}$ was the fixed effect of treatment (moisture and phytase for Exp. 1 and Exp. 2, respectively); and $\mathrm{e}_{\mathrm{ij}}$ was the random error associated with the observation $\mathrm{ij}$.

Experiments 3 to 6 had two factors and were analyzed as a split-plot design. The model used was $Y_{i j}=\mu+X_{i}+$ $Z_{\mathrm{j}}+(X \times Z)_{\mathrm{ij}}+\mathrm{e}_{\mathrm{ij}}$, where $\mathrm{Y}_{\mathrm{ij}}=$ response variable; $\mu=$ mean; main plot $(\mathrm{X}$; Exp. 3: pH 4, 5, and 6; Exp. 4: incubation time 30, 45, and 60 min; Exp. 5: phytase type, 'Quantum Blue' and 'Finase'; Exp. 6: moisture, 50 and 
100\%), subplot (Z; Exp. 3, 4, and 5: HCl, CA, and MA; Exp. 6: HCl, CA, MA, and LA) were both fixed effects; and error was $\mathrm{e}_{\mathrm{ij}}$.

All experimental data were analyzed using the Proc Mixed Model procedure of SAS (2003). LSmeans were determined using the least squares means statement of SAS and were separated using Tukey's multi-treatment comparison method (Saxton, 1998). For all statistical analyses, significance was declared at $p<0.05$. The regression between moisture and phytate concentration was analyzed using the PROC REG procedure of SAS (2003).

\section{Results and Discussion}

The canola meal contained on average $10.3 \%$ moisture, $37.4 \% \mathrm{CP}, 6.6 \% \mathrm{SCP}, 2.5 \% \mathrm{PA}$, and $0.65 \%$ PAP (as is basis), and the initial $\mathrm{pH}$ was 5.8 [2:1 (wt/wt) as water/sample ratio] (data not shown). Phytic acid content in CM in the current study was lower than the range (3.1-6\% PA) reported elsewhere (Cheryan, 1980; McCurdy \& March, 1992; Al-Asheh \& Duvnjak, 1994), while PAP concentration was within the 0.40-0.80\% range reported in CM and 00-rapeseed meal (NRC, 2012; Khan et al., 2013; Weightman et al., 2014), but lower than the 0.78-0.87\% range in canola expeller meals and 00-rapeseed expeller meals (NRC, 2012; Slominski, Jia, Rogiewicz, Nyachoti, \& Hickling, 2012) and 0.04\% higher than 0.70\% PAP observed in CM by Tahir et al. (2012).

Results of Exp. 1, presented in Figure 2, showed that there was a strong and positive correlation between PA degradation level and moisture (PA\% $=2.36-0.00242 \times$ Moisture $\left.\%, r^{2}=0.80, n=46, p<0.001\right)$.

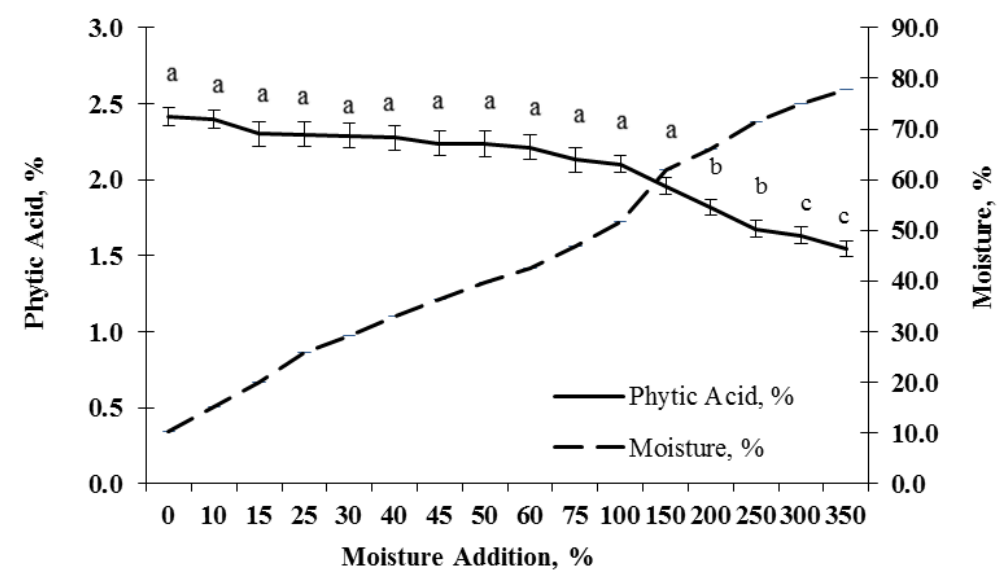

Figure 2. Phytate and moisture contents of canola meal with different moisture additions in a hydrothermal reactor (Exp. 1)

Note. ${ }^{\text {a-c }}$ The different lowercase letters indicate significant difference at $p<0.01 .0=$ Control 0 , solvent extracted canola meal, untreated.

Specifically, with a gradual reduction of PA level with addition of increasing moisture amount, at 200 to $350 \%$ moisture additions (which corresponded to 66 to $77.7 \%$ of the moisture content of the meal) 24.8 to $36 \%$ decreases were observed $(p<0.05)$ compared to the untreated CM. This effect could be related to the high moisture providing favorable condition for the enzyme with increased substrate solubility and access of the enzyme to the substrate and to phytate-bound nutrients. This agrees with much of the literature as indicated in that phytase is inactive in dry conditions, but activated in wet conditions to degrade phytate (Blaabjerg, Carlsson, Hansen-Moller, \& Poulsen, 2010), that moisture greatly influenced the efficacy of phytase and other enzymes increasing phytate hydrolysis in CM (Slominski et al., 1999), and that soaking in water for $2 \mathrm{~h}$ at $30^{\circ} \mathrm{C}$ before feeding increased the efficacy of phytase for apparent $\mathrm{P}$ absorption by $47.7 \%$ and reduced apparent fecal excretion by $18.3 \%$ (Liu, Bollinger, Ledoux, Ellersieck, \& Veum, 1997). Conversely, others have shown that high moisture was deleterious for the intrinsic phytase, especially at high temperatures (Eeckhout, 2000, Esmaeilipour, Van Krimpen, Jongbloed, De Jonge, \& Bikker, 2013).

The high moisture (>150\%) favorable for PA breakdown in CM as shown in Exp. 1, would not be feasible in a feed mill condition due to high energy consumption and costs. Hence, an attempt to create conditions more analogous to a commercial feed mill, 100\% moisture addition was applied to CM in Exp. 2 and others (unless 
otherwise specified). Results of Exp. 2 are displayed in Figure 3.

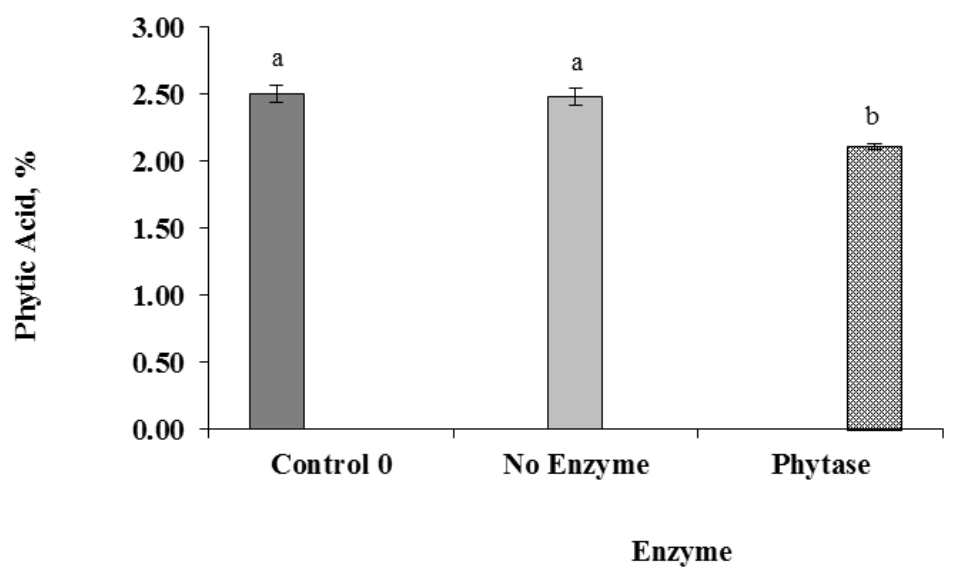

Figure 3. Phytate content of canola meal treated with and without phytase in a hydrothermal reactor (Exp. 2) Note. ${ }^{\text {ab }}$ Bars with different lowercase letters indicate significant difference at $p<0.05$. Moisture condition was $100 \%$. Control $0=$ solvent extracted canola meal, untreated. No Enzyme $=$ solvent extracted canola meal without phytase, but with $100 \%$ moisture addition.

Expectedly, phytate degradation was higher (15.5\%) in CM with phytase (1000 FTU/kg) compared to both, untreated CM $(p<0.05)$ or without phytase, but with $100 \%$ moisture addition $(p<0.05)$ (Figure 3), which was similar to the increased P retention by $14.3 \%$ units, compared with the control diet with phytase, at the same rate as ours, obtained by Emiola et al. (2009), but was lower than the $38.9 \%$ increase by Nelson et al. (1971) with $950 \mathrm{FTU} / \mathrm{kg}$ fungal phytase in broiler chick diet.

In further optimizing HTR condition for CM with phytase and organic acid additions, the results of the experiments (Exp. 3-6) indicated that the enzyme action for breaking down phytate was most effective under $\mathrm{pH}$ 4.0 and $5.0(p<0.05)$ (Figure 4) and all three (30, 45, and $60 \mathrm{~min})$ incubation times $(p<0.05)$ (Figure 5) and acids $(p<0.05)$ (Figures 4, 5, and 6).

The optimal $\mathrm{pH}$ values obtained in the current study were similar to the ranges recorded by others for improved efficacy of the $E$. coli-derived acidic type phytate-degrading enzymes to which the enzyme in the current study belongs to, i.e., between pH 3 and 5 (Newkirk \& Classen, 1998; Menezes-Blackburn, Gabler, \& Greiner, 2015), pH 2 and 4.5 (Adeola et al., 2004), and lower than the optimal pH ranges from 4.5 to 6.0 (Konietzny \& Greiner, 2002). Phytases will differ in their phytate-degrading activities at other than their standard $\mathrm{pH}$ conditions (i.e., $\mathrm{pH} 5.5$ at $37^{\circ} \mathrm{C}$ ), with microbial phytases performing better at $\mathrm{pH}$ values below $\mathrm{pH} 5.5$ (Greiner \& Bedford, 2010).

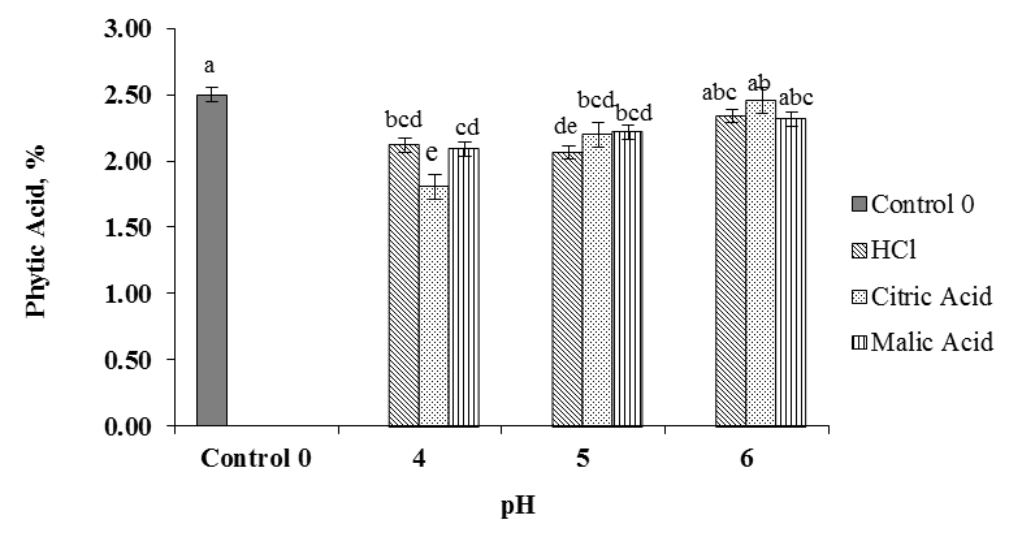

Figure 4. Phytate content of canola meal treated with phytase, at different $\mathrm{pH}$ and acids in a hydrothermal reactor (Exp. 3)

Note. ${ }^{\mathrm{a}-\mathrm{e}}$ Bars with different lowercase letters indicate significant difference at $p<0.01$. A $\mathrm{pH} \times$ acid interaction was detected $(p<0.01)$. Moisture condition was $100 \%$. Control $0=$ solvent extracted canola meal, untreated. 


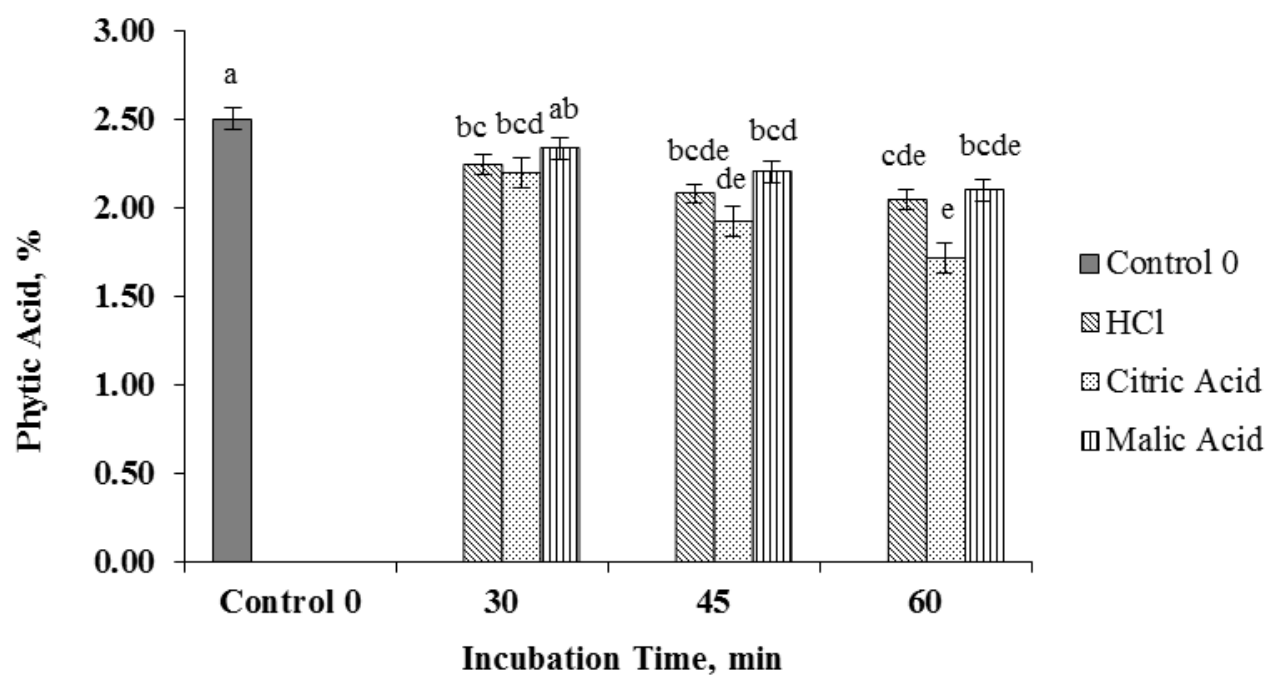

Figure 5. Phytate content of canola meal treated with phytase, at different incubation times and acids in a hydrothermal reactor (Exp. 4)

Note. ${ }^{\mathrm{a}-\mathrm{e}}$ Bars with different lowercase letters indicate significant difference at $p<0.01$. No time $\times$ acid interaction was detected $(p=0.27)$. Moisture condition was $100 \%$. Control $0=$ solvent extracted canola meal, untreated.

Results of the experiments 3-6, also, demonstrated that acid, $\mathrm{pH}$, and incubation time affected phytate degradation $(p<0.05)$. Although, a significant acid $\times \mathrm{pH}$ interaction $(p<0.01)$ was observed, an acid $\times$ time interaction was not detected $(p=0.27)$. Phytase in combination with organic acid and $\mathrm{HCl}$, was more effective in degrading PA at $\mathrm{pH} 4.0$ and $\mathrm{pH} 5.0(p<0.05)$ (Figure 4$)$ and 30-60 min of incubation time of CM in HTR $(p<$ $0.05)$ (Figure 5) with the exception of MA at $30 \mathrm{~min}(p>0.05)$.

Even though, as the results in Figures 3-6 indicated, difference between the effects of $\mathrm{HCl}$ and organic acids on PA was negligible $(p>0.05)$, using organic acids is preferable due to their potential prebiotic benefits (Jongbloed et al., 2000; Dibner \& Buttin, 2002; Tsukahara et al., 2002; Proulx \& Reddy, 2007; Li et al., 2008). Most efficient in degrading PA was the CA treatment with phytase, at $\mathrm{pH} 4.0$, and 30 and 60 min incubated in HTR (by 27.7 and $31.5 \%$, respectively), compared to the untreated CM, with the highest decline in PA being detected with the CA treatment at 60 min of incubation time (by 31.5\%, Exp. 4, $p<0.05$ ).

Bressani, Turcios, de Ruiz, and de Palomo, (2004) reported a 14.9\% loss of PA by cooking whole grain maize for $75 \mathrm{~min}$ with addition of $1.2 \%$ lime, the processing time of which was close to the highest effective time (60 min) detected in the current study. Adeola et al. (2004), in an experiment with E. coli-derived phytase, also, processed the sample in a water bath at $40^{\circ} \mathrm{C}$ for $1 \mathrm{~h}$, analogous to the conditions in the current study. Interestingly, it was observed during our experiments that longer incubation times (to $24 \mathrm{~h}$ ) of CM in HTR with phytase and moisture could lead to $84 \%$ of PA hydrolyzed relative to the initial PA level (data not shown). Likewise, Adeola et al. (2004) observed that during a 24-h incubation with $500 \mathrm{FTU} / \mathrm{kg}$ of $E$. coli-derived phytase $81 \%$ of P was released in corn diet, and water steeping of maize for $8 \mathrm{~h}$ resulted in a $29 \%$ loss of PA regardless of temperature (Bressani et al., 2004). Furthermore, with superdosing fungal phytases, Liu (2014) documented a complete phytate hydrolysis in coproducts of ethanol production within 5-60 min of enzymatic treatment under optimal condition ( $\mathrm{pH} 4.2-4.3$; temperature $50-60^{\circ} \mathrm{C}$ ). These findings support the current results indicating an influence of processing time on phytate degradation. The positive effect of adding organic acids to diets was documented by others, as in Hoehler and Pallauf (1993), the addition of $1.5 \%$ citric acid to a corn-soy diet for young pigs improved $\mathrm{P}$ availability and tended to improve the utilization of $\mathrm{Ca}, \mathrm{Mg}$, and $\mathrm{Fe}$, and in Liem, Pesti, and Edwards Jr., (2008), the addition of citric and malic acids significantly increased the retention of $\mathrm{P}$ and decreased phytate $\mathrm{P}$ in broiler chicks. Interestingly, when fed a diet containing 6\% citrate, CA primarily affected phytate-P utilization in chicks, but had smaller effects in pigs (Boling et al. 2000). As suggested by Han et al. (1998), there may be two possible mechanisms for CA promoting dietary P utilization, it may be enhancing the solubility of digesta $\mathrm{P}$ and the transit time of digesta in the small intestine by lowering digesta $\mathrm{pH}$ (Jongbloed et al., 2000), thereby improving total $\mathrm{P}$ absorption. 
Phytases from different sources typically vary in their activity and recorded in the literature (Leske \& Coon, 1999; Igbasan, Männer, Miksch, Borriss, Farouk, \& Simon, 2000). Two phytase types were tested in HTR Exp. 5, 'Quantum Blue', E. coli-derived 6-phytase and 'Finase', A. niger-derived 3-phytase, and the results are presented in Figure 6.

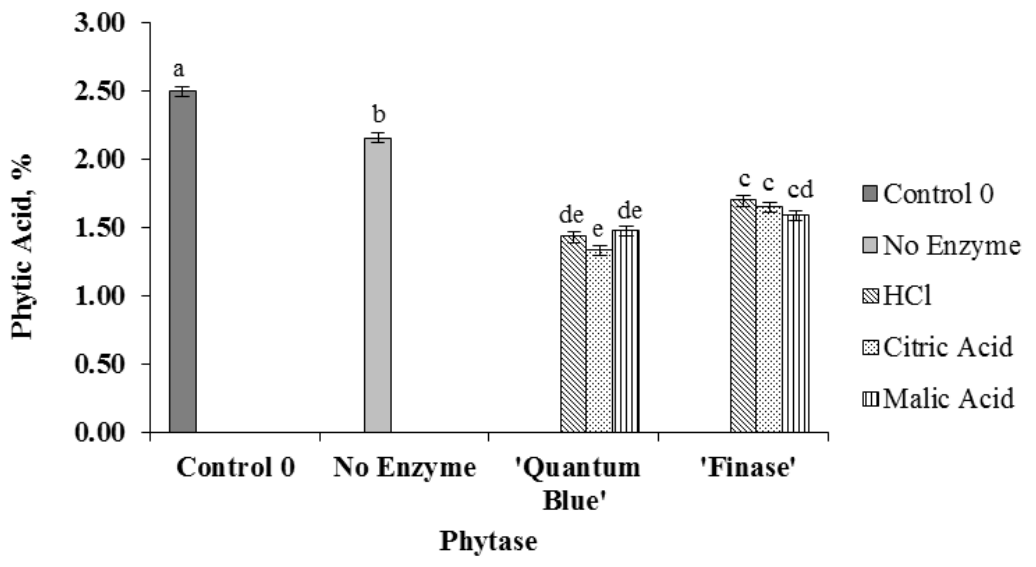

Figure 6. Phytate content of canola meal treated with different phytase types and acids in a hydrothermal reactor (Exp. 5)

Note. ${ }^{\mathrm{a}-\mathrm{e}}$ Bars with different lowercase letters indicate significant difference at $p<0.01$. A phytase $\times$ acid interaction was detected $(p<0.05)$. Moisture condition was $200 \%$. Control $0=$ solvent extracted canola meal, untreated. No Enzyme = solvent extracted canola meal without phytase, but with $200 \%$ moisture addition.

The results demonstrated that acids did not differ $(p>0.05)$, but phytases differed $(p<0.05)$ with 'Quantum Blue' displaying greater phytate hydrolysis (41-46.6\%) than 'Finase' (32.1-36.4\%), although an interaction of acid $\times$ phytase was detected $(p<0.05)$. Similarly, Wilcock (2012) in a study of phytases in pig diets, pointed out that Quantum Blue was more effective than a wild type E. coli phytase in phytate breakdown. Due to the difference in composition, levels and location of phytate (IP6), as well as the contribution of intrinsic phytase in some cereals and oilseeds, the rate of hydrolysis of phytate by microbial phytase can vary to a large extent in these plant-based ingredients (Leske \& Coon, 1999), also, phytases of various microbial origins behave differently with respect to their in vitro properties (Igbasan, Männer, Miksch, Borriss, Farouk, \& Simon, 2000). Moreover, the substrate phytate was reported to act as an inhibitor of many histidine acid phytases (Konietzny \& Greiner, 2002) to which both of the phytases in the current study belonged. Therefore, substrate inhibition must be considered when determining phytate-degrading activity (Bedford, 2000). The greatest decline (46.6\%) of PA in the present study was observed with 'Quantum Blue' phytase in combination with citric acid $(p<0.05)$ compared to control.

Again, differences in the declines in PA with the same phytase and citric acid treatments in Exp. 3 and Exp. 5 (27.7 vs. $46.6 \%$ ) may be explained by the different moisture conditions in the meal (100 vs. 200\%). Even though the high moisture during processing of CM in the HTR was favorable for PA breakdown in CM as the results in the present study suggested (Figures 2-6), in exp. 6, the amount of moisture addition was reduced further (from 100 to $50 \%$ ) to make the treatment application industrially more feasible. As the results showed (Figure 7), PA was similarly influenced with phytase and organic acid under both 50 and $100 \%$ moisture additions with the highest declines in PA $(p<0.05)$ being found for CA treatment (11 and 19.4\%, respectively). 


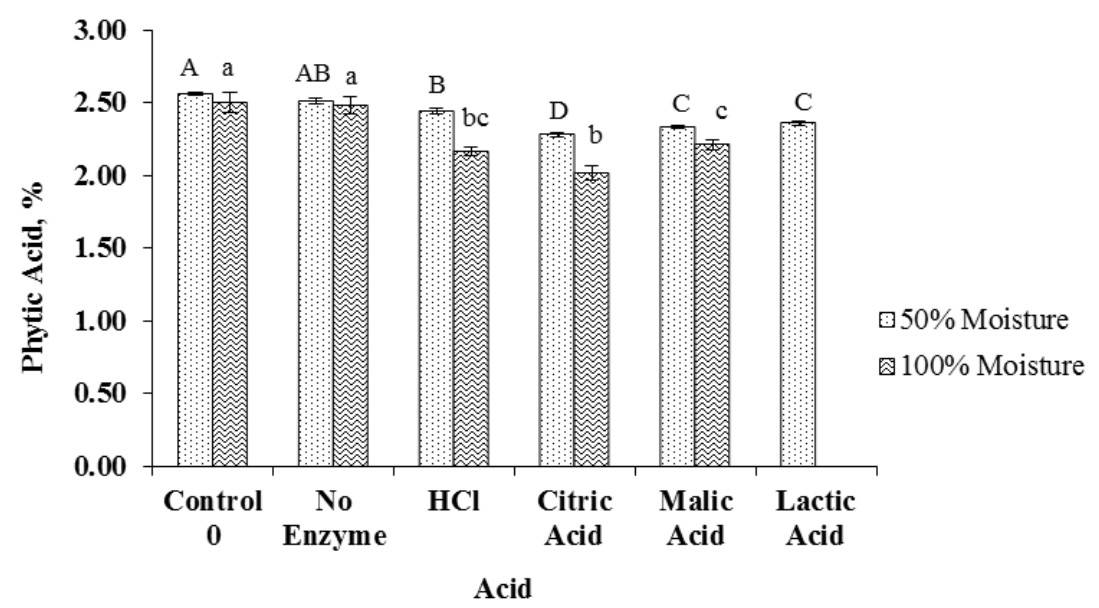

Figure 7. Phytate content of canola meal treated with phytase, different moisture and acid in a hydrothermal reactor (Exp. 6)

Note ${ }^{\text {A-D }}$ Bars with different uppercase letters indicate significant difference within the $50 \%$ moisture treatment at $p<0.01$. ${ }^{\mathrm{a}-\mathrm{c}} \mathrm{Bars}$ with different lowercase letters indicate significant difference within the $100 \%$ moisture treatment at $p<0.01$. Control 0, solvent extracted canola meal untreated. No Enzyme, solvent extracted canola meal without phytase, but with $\mathrm{HCl}$.

Likewise, under 70-80\% moisture conditions of CM with an enzyme cocktail that included phytase, Slominski et al. (1999) obtained the highest degree of phytate hydrolysis (22.5-29.8\%) compared to the control, and $80 \%$ moisture was considered the optimal moisture conditions for enzyme treatment of canola meal. Overall, the results of the present study suggested that CM processing in HTR with a combination of moisture (50 to 100\%), phytase, and organic acid (CA, MA, and LA) at $\mathrm{pH} 4$, for 30 to 60 min would create an effective condition for phytate degradation in the meal, thus improving its quality and utilization for livestock.

\section{Summary and Conclusions}

Findings of the current study indicated that a greater efficacy of phytase can be achieved using hydrothermal pretreatment of CM and with increasing moisture addition (to 350\%) greater phytate degradation was possible. Processing of high moisture feed ingredient, however, would not be feasible in industrial mills, especially in pelleted form (a standard form for monogastrics). Even with less moisture addition (50\%), phytase in combination with organic acid can reduce the PA level (by 11\%) compared to the untreated CM. The optimal condition for reducing phytate in $\mathrm{CM}$ with phytase was determined as $\mathrm{pH} 4$ and $\mathrm{pH} 5$ and 30-60 min incubation time, with temperature, moisture, and phytase rate at $40{ }^{\circ} \mathrm{C}, 100 \%$, and $1000 \mathrm{FTU} / \mathrm{kg}$, respectively. Under this condition, up to a $19.7 \%$ decrease in PA can be achieved, with longer incubation time favoring more reduction. Adding an organic acid provided more favorable condition for phytase as indicated by the higher phytate reduction (by up to 31.5\%) when citric or malic acid was added in the meal. Overall, combination of hydrothermal, phytase, and organic acid pretreatments of $\mathrm{CM}$ would be an effective tool in improving the quality of the meal by reducing the phytate level, thus increasing availability of the nutrients for livestock and decreasing their release to the environment. Certainly, further investigation is crucial for optimizing the efficacy of phytase and other additives during hydrothermal processing of CM to better utilize CM for livestock diet.

\section{Acknowledgements}

This study was funded by the SaskCanola Fund (SaskCanola), Alberta Crop Industry Development Fund Ltd, and Natural Sciences and Engineering Research Council. We thank Dr. T. Scott for helping with obtaining funding and experimental design.

\section{References}

Adeola, O., Sands, J. S., Simmins, P. H., \& Schulze, H. (2004). The efficacy of an Escherichia coli-derived phytase preparation. Journal of Animal Science, 82, 2657-2666. https://doi.org/10.2527/2004.8292657x

Al-Asheh, S., \& Duvnjak, Z. (1994). Effect of glucose concentration on the biomass and phytase productions and the reduction of the phytic acid content in canola meal by Aspergillus carbonarius during a solid-state fermentation process. Biotechnology Progress, 10, 353-359. https://doi.org/10.1021/bp00028a002 
AOAC (Association of Official Analytical Chemists). (2000). Official methods of analysis (17th ed.). Arlington, VA. USA.

Beaulieu, A. D., Bedford, M. R., \& Patience, J. F. (2007). Supplementing corn or corn-barley diets with an $E$. coli derived phytase decreases total and soluble $\mathrm{P}$ output by weanling and growing pigs. Canadian Journal of Animal Science, 87, 353-364. https://doi.org/10.4141/CJAS06032

Bedford, M. R. (2000). Exogenous enzymes in monogastric nutrition - their current value and future benefits. Animal Feed Science and Technology, 86, 1-13. https://doi.org/10.1016/S0377-8401(00)00155-3

Beers, S., \& Jongbloed, A. W. (1992). Effect of supplementary Aspergillus niger phytase in diets for piglets on their performance and apparent digestibility of phosphorus. Animal Science, 55, 425-430. https://doi.org/10.1017/S0003356100021127

Blaabjerg, K., Carlsson, N. G., Hansen-Moller, J., \& Poulsen, H. D. (2010). Effect of heat-treatment, phytase, xylanase and soaking time on inositol phosphate degradation in vitro in wheat, soybean meal and rapeseed cake. Animal Feed Science and Technology, 162, 123-134. https://doi.org/10.1016/j.anifeedsci.2010.09.005

Boling, S. D., Webel, D. M., Mavromichalis, I., Parsons, C. M., \& Baker, D. H. (2000). The effects of citric acid on phytate-phosphorus utilization in young chicks and pigs. Journal of Animal Science, 78, 682-689. https://doi.org/10.2527/2000.783682x

Brenes, A., Viveros, A., Arija, I., Centeno, C., Pizarro, M., \& Bravo, C. (2003). The effect of citric acid and microbial phytase on mineral utilization in broiler chicks. Animal Feed Science and Technology, 110, 201-219. https://doi.org/10.1016/S0377-8401(03)00207-4

Bressani, R., Turcios, J. C., de Ruiz, A. S. C., \& de Palomo, P. P. (2004). Effect of processing conditions on phytic acid, calcium, iron, contents of lime-cooked maize. Journal of Agricultural and Food Chemistry, 52, 1157-1162. https://doi.org/10.1021/jf030636k

Canola Council of Canada. (2014). Industry overview. Retrieved from http://www.canolacouncil.org/markets-stats/industry-overview

Casas, G. A., \& Stein, H. H. (2015). Effects of microbial phytase on the apparent and standardized total tract digestibility of phosphorus in rice coproducts fed to growing pigs. Journal of Animal Science, 93, 3441-3448. https://doi.org/10.2527/jas.2015-8877

Cheryan, M. (1980). Phytic acid interactions in food systems. Critical Reviews in Food Science and Nutrition, 13(4), 297-335, https://doi.org/10.1080/10408398009527293

Cordell, D. (2010). The story of phosphorus: sustainability implications of global phosphorus scarcity for food security. Thesis, Open Publications of UTS Scholars. Retrieved from http://hdl.handle.net/10453/36078

Cromwell, G. L., Stahly, T. S., Coffey, R. D., Monegue, H. J., \& Randolph, J. H. (1993). Efficacy of phytase in improving the bioavailability of phosphorus in soybean meal and corn-soybean meal diets for pigs. Journal of Animal Science, 71, 1831-1840. https://doi.org/10.2527/1993.7171831x

Damiran, D., Lardner, H. A., Larson, K., \& McKinnon, J. J. (2016). Effects of supplementing spring-calving beef cows grazing barley crop residue with canola meal and wheat-based dry distillers' grains with solubles on performance, reproductive efficiency, and system cost. Professional Animal Scientist, 32, 400-410. https://doi.org/10.15232/pas.2015-01479

Darambazar, E. (2018). Method of phytic acid determination in food, feed, and plant materials. Assay protocol, University of Saskatchewan. pp. 4. https://doi.org/10.13140/RG.2.2.14852.27520

de Vries, S., Pustjens, A. M., Kabel, M. A., Kwakkel, R. P., \& Gerrits, W. J. J. (2014). Effects of processing technologies and pectolytic enzymes on degradability of nonstarch polysaccharides from rapeseed meal in broilers. Poultry Science, 93, 589-598. https://doi.org/10.3382/ps.2013-03476

Dersjant-Li, Y., \& Dusel, G. (2019). Increasing the dosing of a Buttiauxella phytase improves phytate degradation, mineral, energy, and amino acid digestibility in weaned pigs fed a complex diet based on wheat, corn, soybean meal, barley, and rapeseed meal. Journal of Animal Science, 97, 2524-2533. https://doi.org/10.1093/jas/skz151

Dibner, J. J., \& Buttin, P. (2002). Use of organic acids as a model to study the impact of gut microflora on nutrition and metabolism. Journal of Applied Poultry Research, 11, 453-463.

https://doi.org/10.1093/japr/11.4.453 
Eeckhout, I. M. (2000). Phytase quality suffers from steam pelleting and storage temperature. Feed Technology, 4, 18-21.

Emiola, A., Akinremi, O., Slominski, B., \& Nyachoti, C. M. (2009). Nutrient utilization and manure P excretion in growing pigs fed corn-barley-soybean based diets supplemented with microbial phytase. Animal Science Journal, 80, 19-26. https://doi.org/10.1111/j.1740-0929.2008.00590.x

Esmaeilipour, O., Van Krimpen, M. M., Jongbloed, A. W., De Jonge, L. H., \& Bikker, P. (2013). The effects of temperature, moisture, duration of incubation time, calcium level, and soaking with water or citric acid on in vitro phytate degradation in a wheat-barley-rye-soybean meal-based diet. Animal Feed Science and Technology, 183, 168-174. https://doi.org/10.1016/j.anifeedsci.2013.05.001

Gao, Y., Shang, C., Saghai Maroof, M. A., Biyashev, R. M., Grabau, E. A., Kwanyuen, P., Burton, J. W., \& Buss, G. R. (2007). A Modified colorimetric method for phytic acid analysis in soybean. Crop Science, 47, 1797-1803. https://doi.org/10.2135/cropsci2007.03.0122

Greiner, R., \& Bedford, M. (2010). Phytase analysis, pitfalls and interpretation of FTU for efficacy in the animal. Proceedings of the 1st International Phytase Summit, pp. 14-22.

Han, Y. M., Roneker, K. R., Pond, W. G., \& Lei, X. G. (1998). Adding wheat middlings, microbial phytase, and citric acid to corn soybean meal diets for growing pigs may replace inorganic phosphorus supplementation. Journal of Animal Science, 76, 2649-2656. https://doi.org/10.2527/1998.76102649x

Hoehler, D., \& Pallauf, J. (1993). Effect of citric acid added to a maize-soya-diet with or without $\mathrm{Zn}$ supplementation on the availability of minerals. AGRIS, 69, 133-142.

Jongbloed, A. W., Mroz, Z., van Derweij-Jongbloed, R., \& Kemme, P. A. (2000). The effects of microbial phytase, organic acids and their interaction in diets for growing pigs. Livestock Production Science, 67, 113-122. https://doi.org/10.1016/S0301-6226(00)00179-2

Igbasan, F. A., Männer, K., Miksch, G., Borriss, R., Farouk, A., \& Simon, O. (2000). Comparative studies on the in vitro properties of phytases from various microbial origins. Archives of Animal Nutrition, 53(4), 353-373. https://doi.org/10.1080/17450390009381958

Khajali, F., \& Slominski, B. A. (2012). Factors that affect the nutritive value of canola meal for poultry. Poultry Science, 91, 2564-2575. https://doi.org/10.3382/ps.2012-02332

Khan, S. A., Chaudhry, H. R., Butt, Y. S., Jameel, T., \& Ahmad, F. (2013). The Effect of phytase enzyme on the performance of broiler flock (a review). Poultry Science Journal, 1(2), 117-125. doi:10.22069/PSJ.2013.1478

Konietzny, U., \& Greiner, R. (2002). Molecular and catalytic properties of phytate-degrading enzymes (phytases). International Journal of Food Science and Technology, 37, 791-812. https://doi.org/10.1046/j.1365-2621.2002.00617.x

Lei, X. G., Ku, P. K., Miller, E. R., \& Yokoyama, M. T. (1993a). Supplementing corn-soybean meal diets with microbial phytase linearly improved phytate phosphorus utilization by weanling pigs. Journal of Animal Science, 71, 3359-3367. https://doi.org/10.2527/1993.71123359x

Lei, X. G., Ku, P. K., Miller, E. R., Yokoyama, M. T., \& Ullrey, D. E. (1993b). Supplementing corn-soybean meal diets with microbial phytase maximizes phytate phosphorus utilization by weanling pigs. Journal of Animal Science, 71, 3368-3375. https://doi.org/10.2527/1993.71123368x

Lei, X. G., \& Stahl, C. H. (2000). Nutritional benefits of phytase and dietary determinants of its efficacy. Journal of Applied Animal Research, 17(1), 97-112. https://doi.org/10.1080/09712119.2000.9706294

Leske, K. L., \& Coon, C. N. (1999). A bioassay to determine the effect of phytate phosphorus hydrolysis and total phosphorus retention of feed ingredients as determined with broilers and laying hens. Poultry Science, 78, 1151-1157. https://doi.org/10.1093/ps/78.8.1151

Li, Z., Yi, G., Yin, J., Sun, P., Li, D., \& Knight, C. (2008). Effects of organic acids on growth performance, gastrointestinal $\mathrm{pH}$, intestinal microbial populations and immune responses of weaned pigs. Asian-Australian Journal of Animal Science, 21(2), 252-261. https://doi.org/10.5713/ajas.2008.70089

Liem, A., Pesti, G. M., \& Edwards, H. M. Jr. (2008). The effect of several organic acids on phytate phosphorus hydrolysis in broiler chicks. Poultry Science, 87(4), 689-93. https://doi.org/10.3382/ps.2007-00256

Liu, J., Bollinger, D. W., Ledoux, D. R., Ellersieck, M. R., \& Veum, T. L. (1997). Soaking increases the efficacy 
of supplemental microbial phytase in a low-phosphorus corn-soybean meal diet for growing pigs. Journal of Animal Science, 75, 1292-1298. https://doi.org/10.2527/1997.7551292x

Liu, K. (2014). Treating thin stillage and condensed distillers solubles with phytase for production of low-phytate coproducts. Cereal Chemistry, 91(1), 72-78. https://doi.org/10.1094/CCHEM-04-13-0072-R

Maenz, D. D. (2001). Enzymatic characteristics of phytases as they relate to their use in animal feeds. In M. R. Bedford \& G. G. Partridge (Eds.), Enzymes in Farm Animal Nutrition (pp. 61-84). CABI Publishing, New York, NY. https://doi.org/10.1079/9780851993935.0061

Maenz, D. D., Engele-Schaan, C. M., Newkirk, R. W., Classen, H. L. (1999). The effect of minerals and mineral chelators on the formation of phytase-resistant and phytase-susceptible forms of phytic acid in solution and in a slurry of canola meal. Animal Feed Science and Technology, 81, 177-192. https://doi.org/10.1016/S0377-8401(99)00085-1

McCurdy, S. M., \& March, B. E. (1992). Processing of canola meal for incorporation in trout and salmon diets. Journal of American Oil Chemists'Society, 69, 213-220. https://doi.org/10.1007/BF02635889

Menezes-Blackburn, D., Gabler, S., \& Greiner, R. (2015). Performance of seven commercial phytases in an in vitro simulation of poultry digestive tract. Journal of Agricultural and Food Chemistry, 63(27), 6142-9. https://doi.org/10.1021/acs.jafc.5b01996

Nelson, T. S., Shieh, T. R., Wodzinski, R. J., \& Ware, J. H. (1971). Effect of supplemental phytase on the utilization of phytate phosphorus by chicks. Journal of Nutrition, 101, 1289-1294. https://doi.org/10.1093/jn/101.10.1289

Newkirk, R. W., \& Classen, H. L. (1998). In vitro hydrolysis of phytate in canola meal with purified and crude sources of phytase. Animal Feed Science and Technology, 71, 315-327. https://doi.org/10.1016/S0377-8401(97)00190-9

NRC. (2012). Nutrient requirements of swine, (11th revised ed.), Models for estimating //nutrient requirements of pigs case studies. Natl. Acad. Press, Washington, DC.

Proulx, A. K., \& Reddy, M. B. (2007). Fermentation and lactic acid addition enhance iron bioavailability of maize. Journal of Agricultural and Food Chemistry, 55, 2749-2754. https://doi.org/10.1021/jf0630015

Roe, M. B., Sniffen, C. J., \& Chase, L. E. (1990). Techniques for measuring protein fractions in feedstuffs. Proceedings of Cornell Nutrition Conference, Department of Animal Science, Cornell University, Ithaca, NY. pp. 81-88.

Sajjadi, M., \& Carter, C. G. (2004). Dietary phytase supplementation and the utilization of phosphorus by Atlantic salmon (Salmo salar L.) fed a canola-meal-based diet. Aquaculture, 240, 417-431. https://doi.org/10.1016/j.aquaculture.2004.07.003

SAS. (2003). User's Guide: Statistics (8th ed.), SAS Inst., Inc., Cary, NC.

Saxton, A. M. (1998). A macro for converting mean separation output to letter groupings in Proc. Mixed. Proceedings 23rd SAS Users Group Int., Cary, NC. pp. 1243-1246.

Schröder, J. J., Cordell, D., Smit, A. L., \& Rosemarin, A. (2009). Sustainable use of phosphorus. Plant Research International, Wageningen, Research Report, UR, EUTender ENV. B. 1/ETU/2009/0025

Simbaya, J., Slominski, B. A., Guenter, W., Morgan, A., \& Campbell, L. D. (1996). The effects of protease and carbohydrase on the nutritive value of canola meal for poultry: In vitro and in vivo studies. Animal Feed Science and Technology, 61, 219-234. https://doi.org/10.1016/0377-8401(95)00939-6

Simons, P. C. M., Versteegh, H. A. J., Jongbloed, A. W., Kemme, P. A., Slump, P., Bos, K. D., Wolters, M. G. E., Beudeker, R. F., \& Verschoor, G. J. (1990). Improvement of phosphorus availability by microbial phytase in broilers and pigs. British Journal of Nutrition, 64, 525-540. https://doi.org/10.1079/BJN19900052

Slominski, B. A., Campbell, L. D., \& Guenter, W. (1992). Enhancement of the feeding value of low-glucosinolate rapeseed by the supplementation of poultry diets with exogenous enzymes. Proceedings of the 19th World's Poultry Congress, Amsterdam, pp. 241-245.

Slominski, B. A., Cyran, M., Guenter, W., \& Campbell, L. D. (1999). Nutritive value of enzyme-treated canola meal. The Regional Institute online publishing.

Slominski, B. A., Jia, W., Rogiewicz, A., Nyachoti, C. M., \& Hickling, D. (2012). Low fiber canola. Part 1. Chemical and nutritive composition of the meal. Journal of Agricultural and Food Chemistry, 60, 
12225-12230. https://doi.org/10.1021/jf302117x

Tahir, M., Shim, M. Y., Ward, N. E., Smith, C., Foster, E., Guney, A. C., \& Pesti, G. M. (2012). Phytate and other nutrient components of feed ingredients for poultry. Poultry Science, 91, 928-935.

https://doi.org/10.3382/ps.2011-01893

Tsukahara, T., Koyama, H., Okada, M., \& Ushida, K. (2002). Stimulation of butyrate production by gluconic acid in batch culture of pig cecal digesta and identification of butyrate-producing bacteria. The Journal of Nutrition, 132, 2229-2234. https://doi.org/10.1093/jn/132.8.2229

van der Peet-Schwering, C. M. C. (1998). Manipulation of pig diets to minimize the environmental impact of pork production in Europe. Proceedings of the 19th Western Nutritional Conference, Saskatoon, SK, pp. 111-120.

Viveros, A., Brenes, A., Arija, I., \& Centeno, C. (2002). Effect of microbial phytase supplementation on mineral utilization and serum enzyme activities in broiler chicks fed different levels of phosphorus. Poultry Science, 81, 1172-1183. https://doi.org/10.1093/ps/81.8.1172

Weightman, R., Garland, P., Phelps, E., Clarke, S., Hazzledine, M., \& Berry, P. (2014). Nutritional value of oilseed rape and its co-products for pig and poultry feed: potential improvements and implications for plant breeders. Research Review No. 80, The final report of project\# RD-2012-3811, Agriculture \& Horticulture Development Board, GB.

Wilcock, P. (2012). Superdosing phytase post weaning to improve pig performance. International Pig Topics, 27(5), 21-23.

Zvomuya, F., Helgason, B. L., Larney, F. J., Janzen, H. H., Akinremi, O. O., \& Olson, B. M. (2006). Predicting phosphorus availability from soil-applied composted and non-composted cattle feedlot manure. Journal of Environmental Quality, 35, 928-937. https://doi.org/10.2134/jeq2005.0409

\section{Copyrights}

Copyright for this article is retained by the author(s), with first publication rights granted to the journal.

This is an open-access article distributed under the terms and conditions of the Creative Commons Attribution license (http://creativecommons.org/licenses/by/3.0/). 